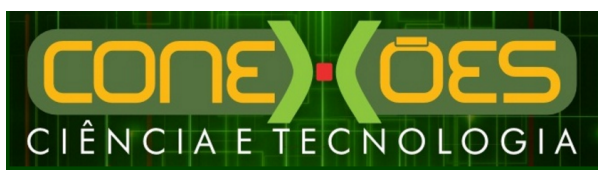

\title{
A QUÍMICA FORENSE COMO FERRAMENTA DE ENSINO ATRAVÉS DE UMA ABORDAGEM EM CTS
}

\author{
Ana Kédyna Ribeiro de Souza ${ }^{1}$, Caroline de Goes Sampaio ${ }^{1}$, \\ Maria Cleide da Silva Barroso ${ }^{1}$, Antônio Marley de Araujo Stedile ${ }^{1}$, \\ antônio Sérgio Araujo Holanda Filho ${ }^{1}$, Francisco Bezerra de Matos Neto ${ }^{1}$, \\ Janaina Lopes Leitinho ${ }^{1}$, Maria Goretti de VASCONCElos Silva ${ }^{2}$
}

${ }^{1}$ Instituto Federal de Educação, Ciência e Tecnologia do Ceará - IFCE, campus de Maracanaú ${ }^{2}$ Universidade Federal do Ceará - UFC

<anakedyna@gmail.com>,<ccleide1971@yahoo.com.br>, <anakedyna@gmail.com> <carol.ifce@gmail.com>, <sergio.holanda.filho@hotmail.com>, <francisco.dbvneto@gmail.com>

DOI: $10.21439 /$ conexoes.v11i6.1124

\begin{abstract}
Resumo. Em geral, o ensino de Química no nível médio ocorre através de metodologias tradicionais e que não se busca uma relação dos conteúdos abordados com a realidade do aluno. Esta dificuldade pode ser minimizada quando trabalhada com temas que relacionem os aspectos da Ciência, Tecnologia e Sociedade - CTS, no universo de sala de aula. A Química Forense é uma temática que desperta e motiva os alunos, pois está presente em seriados de televisão, programa de computadores, entre outros. Dessa forma, este trabalho propôs o uso da Química Forense e seus recursos diferenciados como ferramenta para uma abordagem de Ensino em CTS. O objetivo da pesquisa foi desenvolver um minicurso que trabalhe aspectos teóricos e práticos da Química de forma contextualizada com a Química Forense. Dessa forma, buscou-se favorecer o desenvolvimento da capacidade de observação, investigação, argumentação e conexão entre os fenômenos químicos estudados e os dados observados em processos de perícia, para auxiliar na construção do conhecimento de forma contextualizada e interdisciplinar. Esse trabalho foi aplicado em uma escola pública do município de Maracanaú (CE), com alunos do terceiro ano do ensino médio, num total de 25 em parceria com professores e bolsistas do Programa Institucional de Bolsa de Iniciação à Docência - PIBID do curso de licenciatura em Química do Instituto Federal de Educação, Ciência e Tecnologia do Ceará - IFCE, campus Maracanaú. Ademais, apontou-se como preocupação o desenvolvimento de diversas competências e habilidade para a formação do cidadão. Através dos instrumentais de avaliação aplicados, identificou-se uma maior motivação e empenho dos alunos em aprender. A aplicação do tema relacionado à CTS evidenciou eficácia para a compreensão dos conteúdos abordados, uma vez que permitiu a relação entre a química e o cotidiano do aluno, no que diz respeito aos temas relacionados à Química Forense.
\end{abstract}

Palavras-chaves: Química Forense. Ensino CTS. Cotidiano.

\begin{abstract}
In general, the teaching of Chemistry at the middle level occurs through traditional methodologies and it is not sought a relation of the content addressed with the reality of the student. This difficulty can be minimize when working with themes that relate the aspects of Science, Technology and Society (STS) in the classroom. Forensic Chemistry is a theme that awakens and motivates the students, since it is present in TV series, computer program, among others. In this way, this work proposed the use of Forensic Chemistry and its differentiated resources as a tool for a STS Teaching approach. The objective of the research was to develop a course that works on the theoretical and practical aspects of Chemistry in a way contextualized with Forensic Chemistry. Thus, we sought to promote the development of the capacity for observation, investigation, argumentation and connection between chemical phenomena studied and data observed in processes of expertise, to assist in the construction of knowledge in a contextualized and interdisciplinary way. This work was applied in a public school in the municipality of Maracanaú (CE), with students from the third year of high school, in a total of 25 in partnership with professors and scholars of the Programa Institucional de Bolsa de Iniciação à Docência - PIBID of the licentiate course In Chemistry of the Federal Institute of Education, Science and Technology of Ceará - IFCE, Maracanaú. In addition, it was pointed as a concern the development of several skills and ability for the formation of the citizen. Through the evaluation instruments applied, it was identified a greater motivation and commitment of the students in learning. The application of the subject related to CTS showed efficacy for the comprehension of the contents addressed, since it allowed the relation between the chemistry and the daily of the student, regarding the subjects related to Forensic Chemistry.
\end{abstract}

Keywords: Religious Events. Nossa Senhora das Candeias. Hosting means. 


\section{INTRODUÇÃO}

Conforme as Orientações Curriculares para o Ensino Médio (OCNEM), a Química deve ser ensinada de uma forma que possibilite ao aluno a compreensão dos fenômenos e processos que ocorrem no seu cotidiano, de modo que o discente consiga refletir aspectos importantes da sua realidade, tomando decisões, participando de ações imediatas que tem rebatimentos na vida cotidiana do alunado (BRASIL, 1999).

O Ensino de Química para a formação o cidadão compreende a abordagem de informações químicas fundamentais, que permitam ao aluno "participar ativamente na sociedade, tomando decisões com consciência de suas consequências" (SANTOS; SCHNETZLER 1996, p.29). Os Parâmetros Curriculares Nacionais para o Ensino Médio (PCNEM) sugerem que a organização dos conteúdos de Química considere os conhecimentos escolares de cada aluno, suas histórias pessoais, tradições culturais, relação com os fatos e fenômenos do cotidiano, bem como o coletivo em sua interação com o mundo físico, evidenciando como os saberes científicos e tecnológicos vêm interferindo na produção, na cultura e no ambiente (BRASIL, 1999).

Contudo, em muitos casos, os professores da Educação Básica se deparam com diversas dificuldades na abordagem de metodologias que promovam um ensinoaprendizagem no contexto apontado nos PCNEM. Ademais, o conhecimento é redimensionado, possibilitando ao estudante novas formas de conhecer e vislumbrar o mundo imediato.

A Química é uma ciência que contribui para a elucidação de muitos casos jurídicos, seja através da análise da presença de sangue, avaliação de resíduos de disparos de amas de fogo, identificação de substâncias tóxicas e entorpecentes, contaminantes ambientais, entre outros. Com isso, a Química Forense consiste em uma área da Química que terá como finalidade contribuir para a elucidação de casos de cunho jurídico, de modo a cumprir com a lei a partir das análises de vestígios encontrados no ambiente de um crime(ZARZUELA. 1995; BRUNI; VELHO; OLIVEIRA, 2012).

A natureza da ciência forense consente ao químico a atuação em diversas esferas da perícia. Destacamos a participação em: perícia ambiental, criminal, trabalhista, industrial e na verificação de crime de dopping. Ou seja, suas práticas laborativas assumem grande envergadura, quando se percebe a dime nsão. Dessa forma, a Química Forense trata de temas que despertam bastante interesse nos alunos. Além disso, a criação de seriados de televisão pertinentes ao gênero, tal como o famoso C.S.I. (Crime Scene Investigation), co- laboraram para a boa aceitação da temática.

Este trabalho, portanto, tem como objetivo promover atividades de Química relacionado a perícia forense, a fim de favorecer o desenvolvimento da capacidade de observação, investigação, argumentação e conexão entre os fenômenos estudados e os dados observados, para auxiliar na construção do conhecimento. Com efeito, o cenário apontado possibilita ao discente o desenvolvimento e a potencialização de seus estudos.

O mote desse estudo parte da ciência forense, especialmente à química, onde a dinâmica, doravante descrita, motiva e estimula o interesse do alunado a participar da metodologia. De forma sucinta, o aluno foi situado diante de um crime e teve que o elucidar por meio das evidências forenses, pistas químicas. A opção pelo uso de uma abordagem CTS justifica-se pela pretensão de se promover no ensino da química aquisição de conhecimentos que contribuam para os discentes compreenderem o mundo e suas transformações no âmbito das questões científicas, tecnológicas e sociais. Dessa forma, ensinar química na perspectiva CTS proporciona ferramentas necessárias ao julgamento, avaliação, e tomada de decisão frente às aplicações e implicações sociais do desenvolvimento científico e tecnológico (SILVA et al., 2006).

Por esta via, e conforme o foco no valor atribuído pelos estudantes aos conteúdos químicos, elaborou-se a aplicação e avaliação do minicurso sobre Química Forense com enfoque CTS, abordando através deste tema conceitos de química, tais como: funções orgânicas e inorgânicas, separação de misturas, ligações intermoleculares, reações inorgânicas, solubilidade, toxicologia, onde permite a explicação dos fenômenos supracitados.

Esse trabalho foi aplicado em uma escola pública do município de Maracanaú (CE) com o quantitativo de 25 alunos do terceiro ano do ensino médio, sendo desenvolvido pela docente de Química da referida escola em comum acordo com os professores coordenadores de área, supervisores e bolsistas do Programa Institucional de Bolsa de Iniciação à Docência - PIBID do curso de licenciatura em Química do Instituto Federal de Educação, Ciência e Tecnologia do Ceará - IFCE, campus Maracanaú.

\section{METODOLOGIA DA PESQUISA}

As atividades desse trabalho foram aplicadas na escola estadual Liceu Professor Francisco Oscar Rodrigues, localizado no município de Maracanaú, região metropolitana de Fortaleza (CE). A escola possui $11500 \mathrm{~m}^{2}$ de área, sendo a área construída composta por 14 salas de aula, uma biblioteca, uma sala de multimídias com 
lousa digital, dois Laboratórios de Informática, Laboratório de Química, Física e Biologia, Auditório, Copa, Cantina, Secretaria, Sala dos Professores, Pátio e Quadra poliesportiva. Apresenta 28 turmas, sendo 8 primeiros anos, 10 segundos anos e 10 terceiros anos, divididos nos turnos manhã e tarde, totalizando 1235 alunos. Cada sala de aula possui em média 42 alunos. A escola apresenta ainda 55 professores, sendo 04 professores da disciplina de Química, sendo os últimos todos licenciados.

Inicialmente foi realizada a divulgação do minicurso em cinco turmas dos terceiros anos da referida escola. A seleção dos alunos ocorreu através de uma produção textual, cujos discentes deveriam justificar sua participação no minicurso. Não foram consideradas questões ortográficas, conhecimento químico específico ou afinidade pela disciplina, mas sim, coesão, coerência e relação da proposta com a ciência, tecnologia e sociedade. Foram selecionados cinco alunos de cada turma do terceiro ano do turno matutino, o que corresponde a $10 \%$ de cada sala, na faixa etária de 16 a 18 anos de idade, totalizando 25 alunos participantes.

Os discentes selecionados responderam um instrumental no final do minicurso, em que os itens apontaram para a verificação do interesse pelo estudo de Química, e ainda que metodologia os alunos consideram capaz de possibilitar o entendimento dos conteúdos de Química, além de relacionar os referidos conhecimentos, a vida cotidiana. $\mathrm{O}$ instrumental utilizado foi constituído por questões discursivas e objetivas. As questões tinham múltipla escolha, com o gabarito em uma única opção.

O minicurso de Química Forense trabalhado com os alunos apresentou uma carga horária de 40 horas, cujos encontros apresentaram o seguinte formato:

- Aula teórica relacionada à cena do crime e aplicada a Química forense;

- Apresentação da cena do crime;

- Abordagem de conteúdos teóricos de Química;

- Atividades práticas com análises da Química Forense que dialogam com a cena do crime e com as aulas teóricas.

A trama desenvolvida foi baseada no jogo web free "Investigação Criminal" que a partir de um crime problematiza o ensino de Química Forense de modo que os alunos possam aplicar os conhecimentos adquiridos no minicurso de forma autônoma. Deve-se destacar que o jogo original foi modificado e o enredo transformado em 10 cenas fragmentadas e apresentadas durante o minicurso, destacando-se as pistas deixadas na cena do crime e que continha o assunto da aula a ser trabalhada. Indícios e suspeitos foram acrescentados a fim de aproximar ainda mais a cena do crime aos conceitos e análises da Química Forense.

As aulas teóricas foram ministradas por profissionais convidados da área de ciências da Natureza: Química, Física e Biologia. Foram abordados conteúdos interdisciplinares, dentro do cotidiano do aluno e associado aos conteúdos estabelecidos pelos PCN's para o ensino médio.

Todas as aulas práticas realizadas neste trabalho foram baseadas nas análises que existem nos laboratórios da perícia forense, com as devidas adequações às realidades dos alunos e do laboratório. Para isso, algumas etapas foram adaptadas conforme as disponibilidades dos reagentes e materiais a serem analisados. Mesmo diante dessas adaptações, buscou-se trabalhar de forma coesa com o processo de ensino-aprendizagem do discente, o que explica eventuais substituições e/ou adaptações. No quadro 1 foi apresentada, de forma resumida, as etapas existentes durante o curso de Química Forense.

Cada equipe recebeu um instrumental com objetivo, materiais e métodos, procedimento experimental e questionamentos acerca das atividades práticas, bem como uma explicação simplificada do que teoricamente deveria ser observado.

A atividade de experimentação foi decisória para a inserção dos saberes e práticas relacionados à Química Forense, possibilitando ainda, abordagem nos processos de criminalística, por meio dos exemplos efetivados. Destacou-se assuntos como: testes de precipitação do ferro presente em sangue (CHEMELLO, 2007a, SKOOG; WEST; HOLLER, 2015), a extração do DNA (DE ROBERTIS; HIB, 2001), ensaios cromatográficos e toxicologia forense (COLLINS; BRAGA; BONATO. 2006. PASSAGLI, 2013), identificação de chumbo e bário por precipitação (CHEMELLO, 2007b, SKOOG; WEST; HOLLER, 2015) reconhecimento de impressões digitais (CHEMELLO, 2006).

Os alunos foram divididos de forma aleatória em cinco equipes e cada uma recebeu uma pasta contendo informações quanto à cena do crime e os roteiros das análises (experimentos) a serem realizadas. Os alunos assumiram os papéis de investigadores (peritos) e após a análise dos dados foram incentivados a formular hipóteses sobre a causa textitmortis da vítima.

A avaliação dos conceitos estudados se deu através de um relatório solicitado aos alunos. Neste, foi reque- 
Quadro 1: Apresentação das aulas teóricas e práticas do minicurso de Química Forense.

\begin{tabular}{|c|c|}
\hline AULA TEÓRICA & AULA PRÁTICA \\
\hline $\begin{array}{l}\text { 1)Aula introdutória: } \\
\text { Histórico da Química Forense: conceitos, } \\
\text { áreas de atuação, } \\
\text { técnicas aplicadas para desvendar crimes. } \\
\text { Química forense e sangue: composição do sangue, } \\
\text { conceitos de ácidos e bases, } \\
\text { métodos de identificação de manchas de sangue por } \\
\text { meio de indicadores. }\end{array}$ & $\begin{array}{l}\text { 1) Aula prática introdutória: } \\
\text { Apresentação da cena de um crime } \\
\text { e contextualização do tema com } \\
\text { os alunos. } \\
\text { Avaliação da reação de precipitação do ferro (III) } \\
\text { em meio alcalino. Para essa prática, } \\
\text { foi utilizada solução de } F e(S C N)^{2+} \\
\text { para simular o sangue } \\
\text { (pois a solução apresenta coloração } \\
\text { semelhante ao material biológico). }\end{array}$ \\
\hline $\begin{array}{l}\text { 2)Estudo do DNA: conceitos de ligações químicas, } \\
\text { forças intermoleculares, polaridade das moléculas, } \\
\text { solubilidade e separação de misturas, } \\
\text { extração de DNA, identificações de grupos funcionais } \\
\text { constituintes do DNA. }\end{array}$ & $\begin{array}{l}\text { 2)Extração do DNA da saliva utilizando } \\
\text { solução saturada de } \mathrm{NaCl} \text {, } \\
\text { detergente neutro e álcool etílico. }\end{array}$ \\
\hline $\begin{array}{l}\text { 3)Conceitos da Balística: } \\
\text { mecanismos dos disparos de armas de fogo, } \\
\text { reações nas explosões de projéteis, } \\
\text { testes residuográficos. }\end{array}$ & $\begin{array}{l}\text { 3)Identificação de resíduos de Bário }(\mathrm{Ba}) \text { e } \\
\text { Chumbo }(\mathrm{Pb}) \text { por precipitação. } \\
\text { Simulação de "resíduo" proveniente dos } \\
\text { projéteis. }\end{array}$ \\
\hline $\begin{array}{l}\text { 4)Toxicologia forense: } \\
\text { Identificação e revelação de alcaloides, } \\
\text { toxicidade de drogas e venenos. }\end{array}$ & $\begin{array}{l}\text { 4)Identificação de carbamatos de inseticida } \\
\text { através da cromatografia } \\
\text { em camada delgada (CCD), } \\
\text { utilizando o iodo como reagente de } \\
\text { identificação. A cromatografia é um método } \\
\text { utilizado para separação de misturas }\end{array}$ \\
\hline $\begin{array}{l}\text { 5) Introdução ao estudo } \\
\text { da Papiloscopia, enfocando } \\
\text { principalmente o } \\
\text { ramo da datiloscopia, } \\
\text { caracterização e métodos de identificação } \\
\text { das impressões digitais. }\end{array}$ & $\begin{array}{l}\text { 5)Observação da impressão digital através } \\
\text { da técnica do pó de grafite e em cuba de iodo. } \\
\text { Além disso, foi aplicado o questionário de } \\
\text { avaliação e a elaboração } \\
\text { do relatório das práticas. }\end{array}$ \\
\hline
\end{tabular}


rido a metodologia utilizada pelos discentes para recolhimento de pistas e a análise das amostras e provas do caso encontrado, buscando a apresentação das provas do crime com os conhecimentos químicos adquiridos durante o minicurso. Para apontar os dados, classificouse a opinião dos participantes de acordo com as equipes, denominadas neste trabalho por Equipe 1, Equipe 2,..., Equipe 5, todas com cinco participantes.

No último dia de aula, além do conteúdo abordado e da aula prática, os alunos tiveram que elaborar um relatório intitulado "Fim do Caso". No relatório os alunos deveriam apresentar a causa mortis da vítima baseado nos conteúdos teóricos e práticas abordadas no minicurso. Além disso, responderam a um questionário, o qual foi dividido em duas partes. A primeira visava investigar aspectos referentes à percepção do estudante aos assuntos relacionados à Química. A segunda parte foi composta por questões referentes à metodologia aplicada, na busca da contextualização com a Química Forense.

A formatação, orientação do instrumental, seguiu a proposta anterior, ou seja, verificação do conteúdo estudado, da metodologia operada e se esta logrou êxito. Portanto, o uso do instrumental possibilitou um julgamento e um parecer sobre as concepções dos alunos, se houve mudanças a respeito da teoria e conceitos da química e ainda, da técnica manipulada.

\section{RESULTADOS E DISCUSSÃO}

O trabalho foi conduzido para a aplicação de uma atividade contextualizada, que buscou relacionar a Química com diversas áreas de conhecimento (Biologia, Física, entre outros). Mais do que isso, ao buscar trabalhar com a abordagem de ensino envolvendo a Ciência, Tecnologia e Sociedade - CTS, pretende-se despertar o interesse do discente para uma maior preocupação com o mundo e a busca por compreender como os aspectos das ciências podem interferir na sociedade, buscando o desenvolvimento do cidadão crítico e participativo. Para proporcionar o interesse dos discentes, elegeu-se a temática da Química Forense, pois relaciona os conhecimentos da ciência em questão com a elucidação ou compreensão de crimes, visto que a Química representa uma das áreas de maior abrangência dentro da elucidação da perícia forense (BRUNI; VELHO; OLIVEIRA 2012).

Como forma de despertar o interesse do aluno, foi apontada uma cena de crime (Figura 1), obtida do jogo web free "Investigação Criminal", para que os temas da Química Forense fossem relacionados como "provas" para elucidação do caso. Dessa forma, buscou-se des-

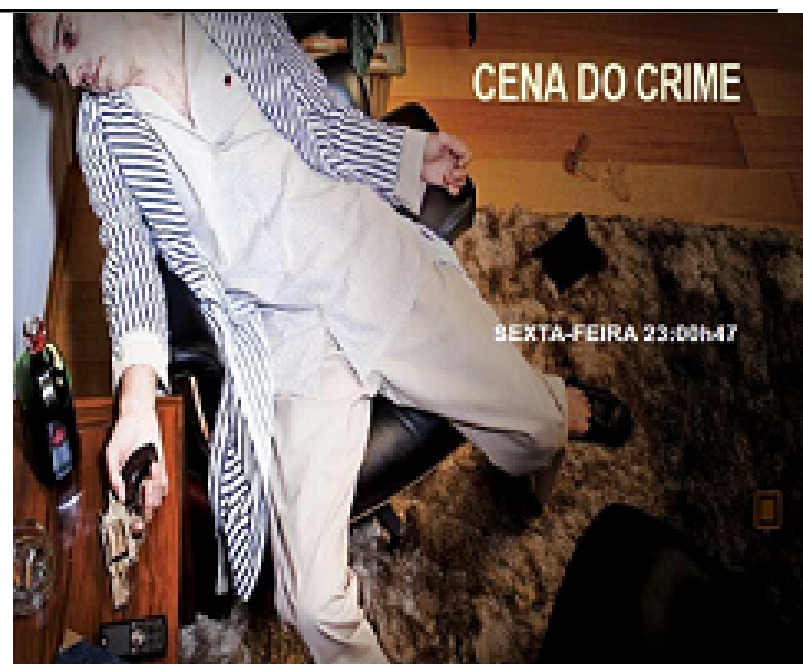

Figura 1: Cena do crime inspirada no jogo web free "Investigação Criminal".

mistificar a Química como sendo uma disciplina fora do contexto social e que não desperta o interesse dos alunos, na qual a sua abordagem em sala de aula ocorre, em geral, apenas por fórmulas, equações matemáticas, equações químicas, entre outros.

O enredo contribuiu para o desenvolvimento da capacidade de investigação, formulação de hipóteses e raciocínio lógico dos alunos, bem como da observação detalhada da situação exposta. Embora o tema abordado não seja, em geral, diretamente ligado ao cotidiano dos discentes, mas muitos acompanham os seriados na televisão ou já escutaram falar do assunto, fazendo com que os conhecimentos adquiridos desenvolvam habilidades nos discentes, tornando-os cidadãos conscientes e com poder de criticidade diante da temática forense.

No relato das equipes acerca do minicurso, diversas opiniões foram surgindo, entre elas, destacou-se o fato de uma maior facilidade em resolver as questões de Química Orgânica, que abordaram classificação de funções, nomenclatura e algumas reações. E dificuldade em resolver questões de Química Geral e FísicoQuímica, citando as questões de ligações intermoleculares e reações inorgânicas como sendo as mais difíceis. Isso ocorreu devido no plano de ensino da referida escola, a Química geral é abordada no primeiro ano do ensino médio, físico-química no segundo ano e Química Orgânica no terceiro ano. De acordo com o referido plano, no período do curso, os alunos do terceiro ano tinham visto recentemente o conteúdo de Química Orgânica citado. Fato que coincide com a justificativa dos 
alunos:

“[...] esse ano estudamos muito Química Orgânica, assim fica mais fácil” (Equipe 1).

"[...] sentimos um pouco de dificuldade nas questões de ligações químicas, também faz tempo que não estudamos essa matéria, apesar de ser considerada fácil" (Equipe 2).

"[...] nem sempre conseguimos diferenciar molécula polar de molécula apolar" (Equipe 3).

"[...] sentimos dificuldade em montar a reação química. Mesmo com todas as fórmulas químicas ali... não conseguimos interpretar a questão". (Equipe 4).

“[...] o problema é que não revisamos o conteúdo dos anos anteriores para fixa-los, agora vimos como vai ser difícil quando chegar o ENEM". (Equipe 5). Contudo, os alunos também consideram relevante a revisão de conteúdo abordada nas aulas:

“[...] se não fosse à aula de hoje, talvez a gente não resolvesse a maioria das questões propostas".

"[...] entendemos o contexto e fazemos parte dele, por isso fica mais fácil fixar o conteúdo". Dessa forma, foi possível constatar o quão importante é o processo de ensino-aprendizagem quando se faz inserida a participação ativa do aluno, tornando significativo o conhecimento hora adquirido. Além disso, os PCNEM ressaltam a importância de tornar o aluno um agente participante na busca do conhecimento e na dinâmica do ambiente escolar:

\begin{abstract}
A simples transmissão de informações não é o suficiente para que os alunos elaborem suas ideias de forma significativa. É imprescindível que o processo de ensino-aprendizagem decorra de atividades que contribuam para que o aluno possa construir e utilizar o conhecimento(BRASIL 1999 p.93)
\end{abstract}

A seguir, apresenta-se e discute-se acerca das aulas práticas realizadas durante o minicurso de Química Forense, bem como a importância do referido curso à luz da visão do alunado.

A primeira atividade prática foi a identificação de sangue. Os materiais e reagentes foram de fácil acesso e geralmente presentes nos laboratórios das escolas de ensino médio: hidróxido de amônia concentrado, ácido

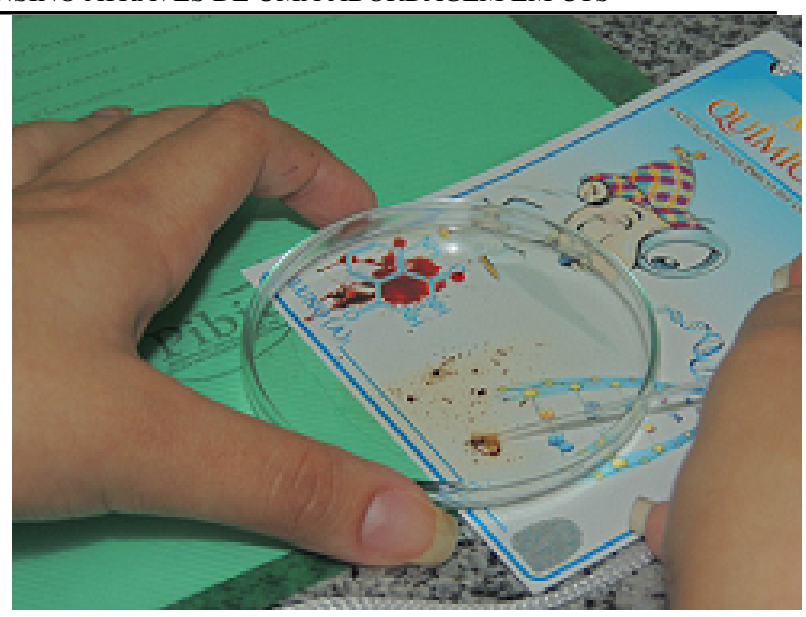

Figura 2: Precipitação de $F e^{+3}$ do "sangue" - Atividade prática 01.

acético glacial e cloreto de sódio $1 \%$. Nessa prática permite a abordagem do conteúdo de funções inorgânicas e reações químicas. Explicar reações conforme Figura 2. É importante destacar que nessa prática, o sangue foi adaptado, pois tratava-se de uma solução de $[F e(S C N)]^{2+}$, solução que apresenta coloração semelhante a do sangue. Com isso, foi possível que a atividade pudesse ser realizada, visto que a extração de sangue não era possível.

Na segunda aula prática, para a extração de DNA, a técnica aplicada para o isolamento do material genético da saliva fazia uso de diferentes reagentes. O detergente tem a função da desestruturação da membrana lipoproteica das células, para obtenção do DNA, contido no núcleo. O álcool etílico é utilizado para que ocorra o agrupamento do DNA, devido a sua baixa polaridade.

Conforme apontado na figura 3 , o experimento da extração e separação do material genético (DNA) foi um momento significativo para os alunos, aproximando-os dos assuntos teóricos adquiridos em sala, visto que a prática possibilitou a observação de uma técnica fácil para a extração do DNA, tornandose viável abordar os assuntos de solubilidade química, composição do DNA, entre outros, tornando-os de fácil compreensão e permitindo a visualização de todo o processo.

A terceira atividade prática consistiu na análise de disparos de armas de fogo (REIS et al., 2004). Como no ato do disparo de armas de fogo existem resíduos de metais, como bário $(\mathrm{Ba})$, chumbo $(\mathrm{Pb})$, provenientes de explosivos como sais de chumbo, bário de crime fictícia além de resíduos sólidos e gasosos presentes no projétil, da detonação da mistura iniciadora e da pólvora. (TOC- 


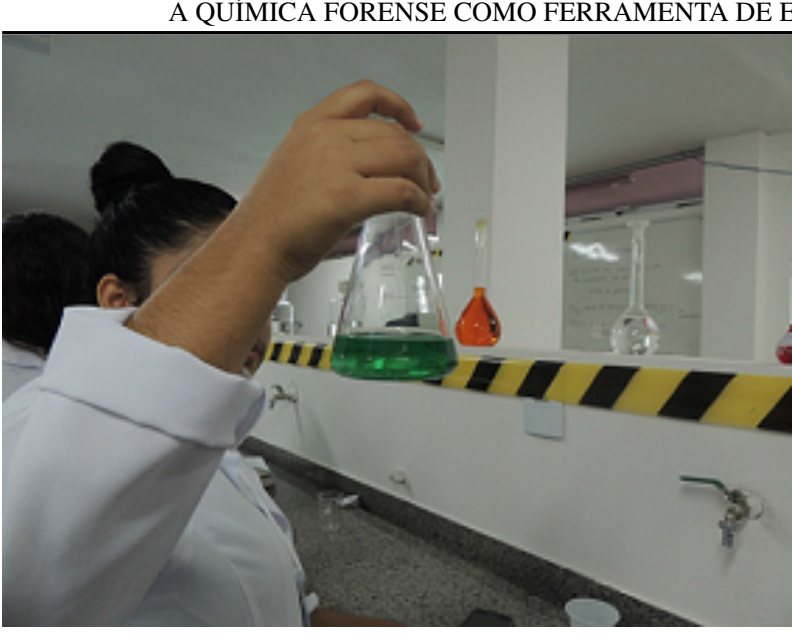

Figura 3: Observação do DNA extraído das células da mucosa bucal

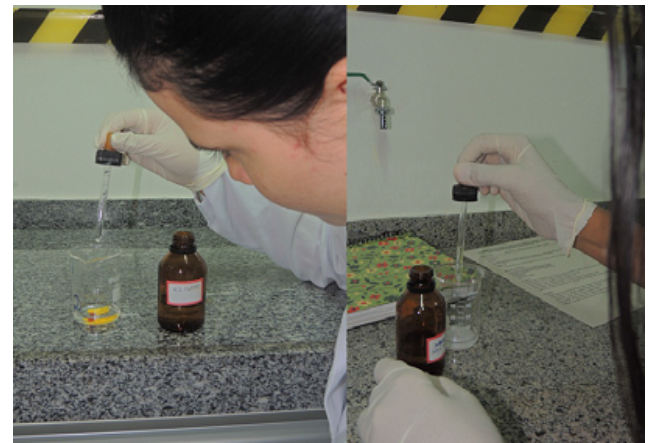

Figura 4: Reação de precipitação. Amostra 1 - positivo para chumbo. Amostra 2 - positivo para bário

CHETTO, 2009). As amostras foram previamente preparadas com sais de chumbo e bário (tomando os devidos cuidados com o manuseio das soluções), sendo denominadas de amostra $1(\mathrm{~Pb})$ e amostra $2(\mathrm{Ba})$. Foram utilizadas duas soluções precipitantes (Figura 4). A reação química envolvida no processo consiste: identificação de chumbo $\left(\mathrm{Pb}_{2+}\right)$ e bário $\left(\mathrm{Ba}_{2+}\right)$ através da precipitação desses cátions, na forma de iodeto $\left(\mathrm{PbI}_{2}\right)$ e sulfato $\left(\mathrm{BaSO}_{4}\right)$., respectivamente (ROSA; SILVA; GALVAN, 2014). Segue as reações químicas citadas:

$\mathrm{BaCl}_{2(a q)}+\mathrm{Na}_{2} \mathrm{SO}_{4(a q)} \rightarrow \mathrm{BaSO}_{4(s)} \downarrow+2 \mathrm{NaCl}_{(a q)}$

$$
\mathrm{Pb}\left(\mathrm{NO}_{3}\right)_{2(a q)}+2 \mathrm{KI} \rightarrow \mathrm{PBI}_{2(s)} \downarrow+2 \mathrm{KNO}_{3(a q)}
$$

$\mathrm{Na}$ prática de cromatografia em camada delgada (CCD) foi possível realizar a identificação de carbamatos, presentes em muitos inseticidas (figura 5). Em ge-

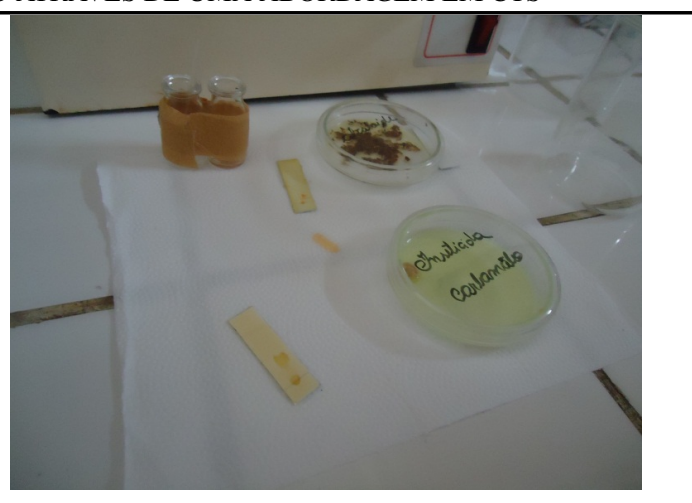

Figura 5: Cromatografia em camada delgada - carbamato

ral, a análise do carbamato foi muito importante para os alunos, pois foram trabalhados os assuntos de solubilidade, forças intermoleculares, gradiente de eluição de solventes, polaridades moleculares e as características da técnica de CCD para a separação de misturas. É importante também destacar que na aula teórica foram abordados os prejuízos à saúde causados por essas substâncias, visto que na perícia forense se realiza muitas análises de alcaloides e carbamatos por CCD (FARIAS. 2007), principalmente para a identificação de diversos entorpecentes e/ou de inseticidas comerciais, que por sua vez, são frequentemente utilizados em tentativas de suicídio ou homicídios por envenenamento. Buscou-se destacar todos os aspectos químicos que estavam envolvidos na técnica e apontar o quanto a Química é importante nos processos da perícia forense. Como ensinar não é uma mera transmissão de conhecimentos, mas uma forma de debater conceitos, formular ideias, trazer os conteúdos elaborados de forma prática. A química toxicológica perpassa por todos esses processos, fazendo com que o aluno compreenda de forma simples aquilo demonstrado em sala de aula.

A última atividade prática foi a revelação de impressão digital. Foram utilizadas as técnicas do pó de grafite, para revelar a impressão digital (Figura 6) bem como identificação do código datiloscópico (Figura 7).

A outra técnica aplicada para a identificação das digitais foi através do método do vapor de iodo (figura 8). Ela consiste na absorção deste vapor pelos compostos gordurosos que podem estar presentes nas mãos, fazendo com que os vapores de iodo interajam e, portanto, as impressões digitais são identificadas.

Como é possível observar na figura 9 , destacou-se a identificação da impressão digital de uma das equipes desse minicurso pela utilização da técnica de iodo. A fotografia ocorreu de forma rápida, pois o vapor de iodo 


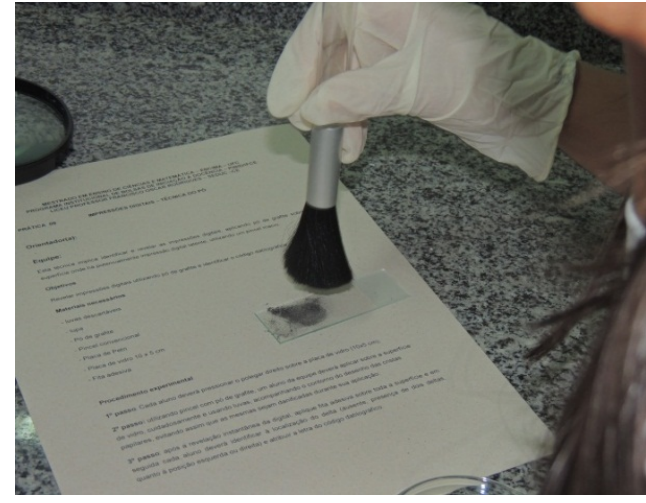

Figura 6: Digitais reveladas com a Técnica do pó de grafite.

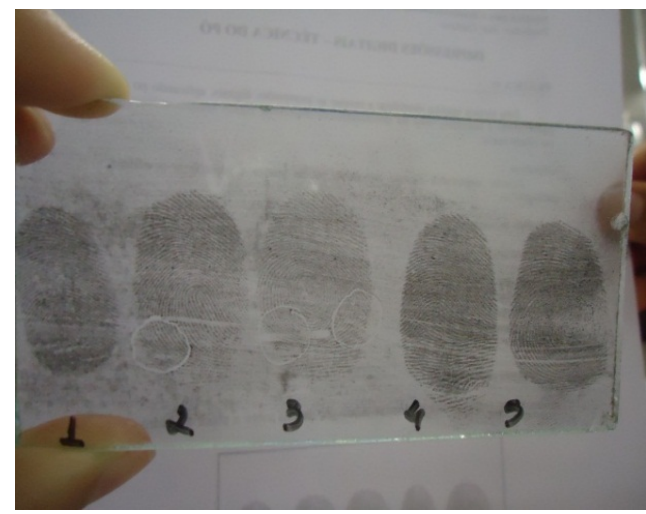

Figura 7: Código datiloscópico identificado com a Técnica do pó de grafite.

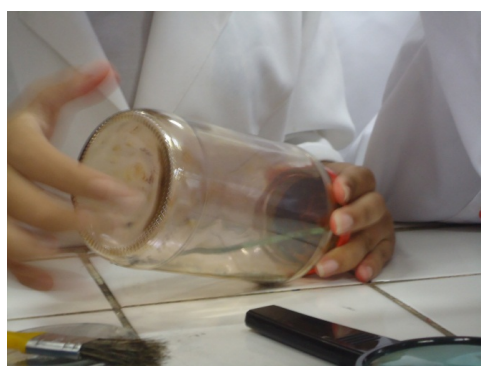

Figura 8: Revelando impressão digital com a Técnica do Vapor de Iodo.

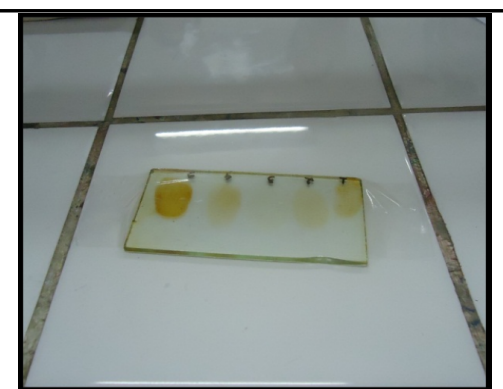

Figura 9: Impressões digitais por vapor de iodo.

irá também desprender-se, depois de algum tempo. Havendo a identificação da impressão digital, no caso dos processos de perícia forense, o material é encaminhado para o reconhecimento da digital com o recurso de dados nacionais de identificação datiloscópica.

Esse momento possibilitou que os alunos aprendessem a discutir, apresentar suas opiniões, desenvolver o poder de argumentação e trabalhos em equipe, favorecendo a relação aluno-aluno, aluno-professor, alunosociedade.

[...] a Química pode ser um instrumento da formação humana que amplia os horizontes culturais e a autonomia no exercício da cidadania, se o conhecimento químico for promovido como um dos meios de interpretar o mundo e intervir na realidade, se for apresentado como ciência, com seus conceitos, métodos e linguagens próprios, e como construção histórica, relacionada ao desenvolvimento tecnológico e aos muitos aspectos da vida em sociedade (BRASIL, 2002, p.87)).

Quando questionados quanto ao melhor método para compreender o conteúdo de Química, a maioria dos alunos optou por aulas teóricas $(25 \%)$ e atividades práticas (32\%) - Figura 10 Para GALIAZZI e GONÇALVES (2004), a atividade experimental é uma maneira eficiente para complementar o ensino de Química, tornando as aulas mais interessantes, promovendo o estímulo pelo aprendizado discente.

Além disso, é importante destacar que $25 \%$ dos discentes apontaram a aula teórica como uma maneira importante de se obter o conteúdo. Isso só destaca a relevância que se existe em aliar a teoria com a prática, buscando sempre a aproximação da aula teórica com temas sociais.

Com base na avaliação do aluno sobre a sua satisfação em estudar Química, observou-se que $80 \%$ dos 
Qual a maneira que compreende melhor o conteúdo de química?

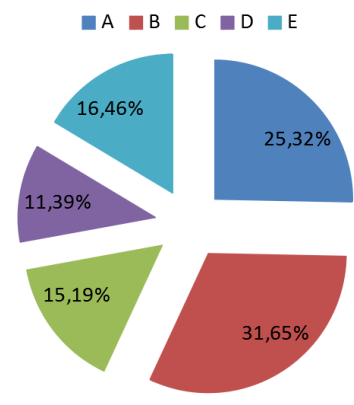

Figura 10: Métodos de ensino

Legenda:

(A) Aulas teóricas

(B) Aulas práticas

(C) Exercícios

(D) Livro didático

(E) Por meio de recursos audiovisuais (ex. multimídia, filmes, músicas)

alunos gostam da disciplina, mas apresentava dificuldade em compreender os conteúdos. Apesar de saberem que o estudo de Química é importante e que está ligado ao cotidiano, tiveram dificuldade de citar exemplos. Para 96\% dos alunos, os conteúdos que lhes são ensinados não se relacionam com o seu cotidiano social e/ou tecnológico. Por isso, se faz necessário o uso de metodologias que promovam essa conexão.

\begin{abstract}
A função do ensino de química deve ser a de desenvolver a capacidade de tomada de decisão, o que implica a necessidade de vinculação do conteúdo trabalhado com o contexto social em que o aluno está inserido (SANTOS; SCHNETZLER 1996 p.30).
\end{abstract}

Com a segunda parte do questionário, foi possível constatar o quanto a aplicação desse minicurso, como metodologia diferenciada de ensino, permitiu que os alunos adquirissem uma crescente motivação pelo conhecimento e estudo da Química. Observou-se que 95\% dos alunos (Figura 11) destacaram a importância do uso de novas metodologias de ensino para a Química, ressaltando a importância deste trabalho. Assim, pôde-se quebrar o paradigma de que essa ciência é de difícil compreensão e que não apresenta relação com cotidiano.

Ainda com base nas informações obtidas do questionário, é importante inferir que todos os alunos apontaram para a importância de aulas diferenciadas, aplicando temas interdisciplinares e contextualizados. Além disso, a aplicação de atividades experimentais foi um complemento para a fixação dos conteúdos da aula

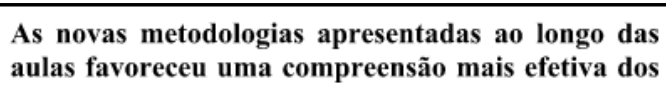
assuntos abordados?

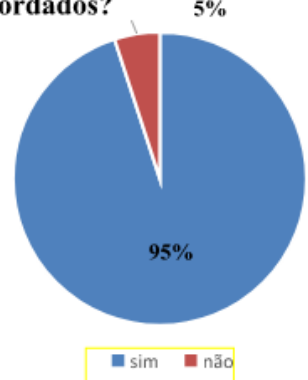

Figura 11: Avaliação da metodologia aplicada ao logo do minicurso de Química Forense .

teórica.

É importante destacar também da satisfação dos alunos na participação dessa atividade. Não houve atribuição de nota, prêmios e/ou intervenção nas aulas curriculares. As atividades que foram apresentadas nesse trabalho foram de participação voluntária dos alunos e contou com frequência média de $88 \%$ durantes as aulas. Destacando, assim, a importância desse trabalho para o meio escolar e para a formação de um cidadão crítico.

\section{CONSIDERAÇÕES FINAIS}

O minicurso de Química Forense possibilitou uma aproximação dos conteúdos da Química aos temas que norteiam à perícia, tornando a disciplina mais atrativa e com a possibilidade de realizar, na prática, diversas metodologias laboratoriais vivenciadas pelos peritos, mesmo diante de diferentes adaptações à realidade escolar.

Com isso, destaca-se o fato dos alunos revisarem conteúdos importantes do ensino médio, de modo que refletissem sobre as atividades propostas, compreendendo como a Química está inserida não apenas em investigações criminais, entretanto situações também encontradas na nossa realidade.

Os principais resultados evidenciaram diferenças na atitude dos alunos com desenvolvimento de competências e habilidades, permitindo o resgate do interesse dos estudantes para a Química, contribuindo positivamente com a aprendizagem dos conteúdos formais da disciplina.

Observou-se que, ao buscar pelas peculiaridades arraigadas na existência da comunidade escolar, o aluno destacou a busca por estratégias de ensino diferenciadas, que favoreçam a relação com o contexto social e tecnológico. Com isso, o discente passa a ser um agente 
transformador na construção do conhecimento, contribuindo com as mudanças de sua realidade.

Nesse contexto, o emprego de temas químico sociais nas aulas de química potencializou a capacidade de motivação dos estudantes em aprender conteúdos abordados, uma vez que, os temas são extraídos de seu cotidiano e que utilizam conhecimento já adquirido, seja no contexto local, regional, nacional ou mundial. A possibilidade de desenvolver os conteúdos a partir das contradições viabiliza, sem maiores obstáculos, a problematização.

\section{REFERÊNCIAS}

BRASIL. Conhecimentos de química. ciências da natureza, matemática suas tecnologias - parte III. In: Parâmetros Curriculares Nacionais: Ensino Médio. Brasília: Minitério da Educação, 1999.

. Orientações educacionais complementares aos parâmetros curriculares nacionais - ciências da natureza, matemática e suas tecnologias. In: Parâmetros Curriculares Nacionais: Ensino Médio. Brasília: Minitério da Educação / Semtec, 2002.

BRUNI, A. T.; VELHO, J. A.; OLIVEIRA, M. F. Fundamentos de Química Forense-uma análise prática da química que soluciona crimes. Campinas, SP: Millennium Editora, 2012.

CHEMELLO, E. Ciência forense: Impressões digitais. Química Virtual, p. 1-10, 2006.

. Ciência forense: balística. Química Virtual, p. 1-10, 2007.

Ciência forense: Manchas de sangue. Química Virtual, p. 1-10, 2007.

COLlins, C.; BRAGA, G.; BONATO, P. S. Fundamentos de cromatografia. Campinas: Editora Unicamp, 2006. v. 42.308 - 308 p. ISBN: 85-268-0704-8.

DE ROBERTIS, E. M. F.; HIB, J. Bases da biologia celular e molecular. 3. ed. Rio de Janeiro: Guanabara Koogan, 2001.

FARIAS, R. F. Introdução à química forense. Campinas, SP: Editora Átomo, 2007.

GALIAZZI, M. C.; GONÇALVES, F. P. A natureza pedagógica da experimentação: uma pesquisa na licenciatura em química. QuÃmica Nova, v. 2, p. 326 331, 2004.
PASSAGLI, F. M. Fundamentos de cromatografia. 4. ed. Campinas, SP: Millenium Editora, 2013. v. 42. 308 - 308 p.

REIS, E. L. T.; SARKIS, J. E. S.; RODRIGUES, C.; NETO, O. N.; VIEBIG, S. A. Identificação de resíduos de disparos de armas de fogo por meio da técnica de espectrometria de massas de alta resolução com fonte de plasma indutivo. Quim. Nova, SciELO Brasil, v. 27, n. 3, p. 409-413, 2004.

ROSA, M. F.; SILVA, P. S.; GALVAN, F. B. Ciência forense no ensino de química por meio da experimentação. Química Nova na Escola, São Paulo SP, p. 1-9, 2014.

SANTOS, W. L. P.; SCHNETZLER, R. P. Função social: o que significa ensino de química para formar o cidadão. Química Nova na Escola, n. 4, 1996.

SILVA, M. J. et al. Dissertação de Mestrado, Programa de Pós-Graduação em Educação Científica e Tecnológica, $O$ ensino de CTS através de revistas de divulgação científica. Florianópolis, SC: Universidade Federal de Santa Catarina, 2006.

SKOOG, D. A.; WEST, D. M.; HOLLER, F. J. Fundamentos de química analítica. São Paulo: Cengage Learning, 2015. v. 2.

TOCCHETTO, D. Balística Forense - Aspectos Técnicos e Jurídicos. 8. ed. Campinas, SP: Millennium Editora, 2009. I.S.B.N.: 978-85-7625-332-7.

ZARZUELA, J. L. Química legal. In: TOCHETTO, D. (Ed.). Tratado de perícias criminalísticas. Porto Alegre: Ed. Sagra-DC Luzzatto, 1995. 